\title{
FUNCTION OF WATER IN THE LANDSCAPE OF THE VILLAGES IN THE PAST AND IN PRESENT, ON EXAMPLE OF VILLAGES IN LOWER SILESIA
}

\author{
Irena Niedźwiecka-Filipiak' ${ }^{1}$, Liliana Serafin ${ }^{1}$ \\ 1 Institute of Landscape Architecture, Wrocław Universiy of Environmental and Life Sciences, pl. Grunwaldzki \\ 24a, 50-363 Wrocław, Poland, e-mail: irena.niedzwiecka-filipiak@up.wroc.pl
}

Received: 2014.10.15

Accepted: 2014.11.14

Published: 2015.01.02

\begin{abstract}
Since ancient times, water was associated with colonization, being one of the main factors determining the localization of both cities and villages. Rivers, streams, water reservoirs were also the element contributing to the attractiveness of the rural landscape. Initially, the function of surface waters in the rural areas was limited to utility and connected with farm production. With time, the surface waters started being used for energy production and for industrial purposes. Proper management of surface waters also contributes to increase retention and reduce the risk of flooding. With time, streams and ponds became being used in mansion parks, which have been the endeavor enriching the composition. Today, rivers and water reservoirs in the villages no longer play such a significant utility and industrial role. Their function changed into mainly decorative and recreational. However, in many places the potential of using the areas adjoining rivers and ponds is not used by the village residents, which result in backfilling small water reservoirs in the villages and closing the visibility of flowing streams.
\end{abstract}

Keywords: surface waters, rural landscape, rivers, ponds.

\section{INTRODUCTION}

Rural landscape was shaped by many factors. One of them were the anthropogenic processes that are a blend of cultural, social and economic factors [Marcucci 2000]. Significant element of the rural landscape are the surface waters. They are the one of the most important components of the natural environment, having the impact on the attractiveness of the landscape [Iwicki 1997]. Water for centuries had a profound influence on the location and development of settlements. The water was the element, which was the basis for the existence of rural residents. Initially settlements were located in close proximity or near the natural forms of surface waters. Thus, in the rural landscape there are ponds, rivers and streams, which frequently were performing utility, farm and disposal functions [Borcz, Pogodziński 1994]. In rural areas, reservoirs and watercourses, although performing utility functions, influenced on a large diversity of landscapes [Wagner 2005].
With the development of civilization, the man used the water, increasingly transforming the landscape by creating new forms of water reservoirs and watercourses [Borcz, Potyrała 1993]. During this time, the rank of water has increased from basic, connected with the everyday life of rural residents, to more advance use of water as an energy source, which was the basis for creating a variety of industries. The other new function of water was a decorative one, within the development of the palace and park complexes. This application appeared most frequently in the case of palace parks and gardens, which often were located deliberately near rivers. In the composition both natural elements like oxbow lakes, springs, streams and other watercourses, as well as artificial water features (ponds, canals, fountains) were used [Bernat 2003]. In many villages the whole systems of water management were created, allowing retention of the excess water, as well as the possibility of obtaining it in times of shortage. Today we often underestimate the importance of water in shaping the rural landscape. Many of the 
old water reservoirs inside the built-up areas of the villages are backfilled without analyzing their historical role and the watercourses are covered and hidden. This causes not only the consequence of depletion of the rural landscape in terms of scenic view, but also periodic flooding of buildings, which is often a big surprise for residents.

The question must be asked whether nowadays the role of surface waters in shaping the rural landscape is appreciated and whether these resources are used by the rural society in the right way. Natural capital that brings many benefits for society are varied and multifunctional landscapes [de Groot 2006]. One of the most important elements of these landscapes are surface waters. Therefore, so important objective of water management in agriculture and rural areas is protection of surface waters against improper or excessive exploitation. Now a serious threat against the achievement of these objectives is intense urbanization and fragmentation of rural areas. As a result of these processes, the existing natural, water supply and drainage systems are threatened by destruction [Kaca 2009].

\section{MATERIAL AND METHODS}

\section{Surface waters in the villages in Wisznia Mała Commune}

Initially, the surface waters in the villages were used mostly for utility purposes. During this time, together with buildings and whole village development of each village, surface waters fitted to the natural environment. Work and life of the rural society in a natural way was linked with nature and its cycles. Both, the watercourses and water reservoirs had influence on rural landscape. The build-up areas in the villages were localized and shaped depending on the location of the village relative to the flowing stream. The strongest impact had the streams flowing inside the village, along the buildings, due to the need of taking into account the flood plain, without the possibility of situating any buildings there. It was necessary to build watercourse crossings to individual farms located on the other side of the stream. Sometimes two roads on both sides of the river with several major crossings connecting the two parts of the village were built. Along the rivers, high vegetation was planted, mostly fruit trees. An equally important role in the village was played by water reservoirs whose function and importance varied with changes of the rural areas. Ponds located in the center of the village, one or more, over time became in many cases fire protection reservoirs with concreted edges and gridded, metal fence. Previously available for all village residents, at this time completely cut off from the possibility of close contact with them. This process has also unfavorable visual reflection by isolation of the space and raw concrete edges of the banks.

In order to test these issues the villages from the Wisznia Mała commune from Lower Silesia Region were selected. In these villages the changes in terms of surface waters, that occurred up over time, were examined. Analyses were carried out on the basis of the comparison of the messtischblatt maps from the early twentieth century with contemporary maps and on the basis of field surveys. Also the studies conducted in 2002 [Niedźwiecka-Filipiak 2002] were used to determine whether last years had positive impact on the approach of the village residents and local authorities to the subject. In 2002 it was demonstrated that the role of surface waters had still great importance, despite the loss of a number of water reservoirs in recent years. The aim of the analysis was to determine what is the quantitative situation of water reservoirs now and also if the actions of the village residents and local authorities have recently had a positive impact on this situation. Another issue is whether the landscape potential of surface waters in the villages is used through proper management of their surroundings.

The commune of Wisznia Mała is located in the immediate vicinity of Wroclaw, bordering it from the north side. It is therefore situated in the area of strong suburbanisation processes, but it is also a potential place of recreation for Wroclaw's inhabitants [Niedźwiecka-Filipiak, 2013]. Figure 1 shows on a graphical scheme the changes that have taken place in this area in comparison to the year 1942. In most of the villages the built-up areas has expanded and some of them have merged with each other (Rogoż with Kryniczna or Ligota Piękna with Wisznia Mała). The villages Raków and Cienin also underwent significant changes. These villages have been almost totally razed to the ground (Cienin) and the greater part of the land is utilized as a military training ground. Currently in part of the former Raków built-up area the Toya golf course has been built, together with a housing estate.

The studied area is located in the river basin of Widawa, which runs through the south-western 
part of the area. Table 1 shows that at present only one village in the whole Wisznia Mała commune has no surface waters. It is the village Piotrkowiczki. However, in the first half of the twenti- eth century, also in this village there were two small ponds within residential areas, which have not survived to the present day. In three villages there are small watercourses Ława and Mienia

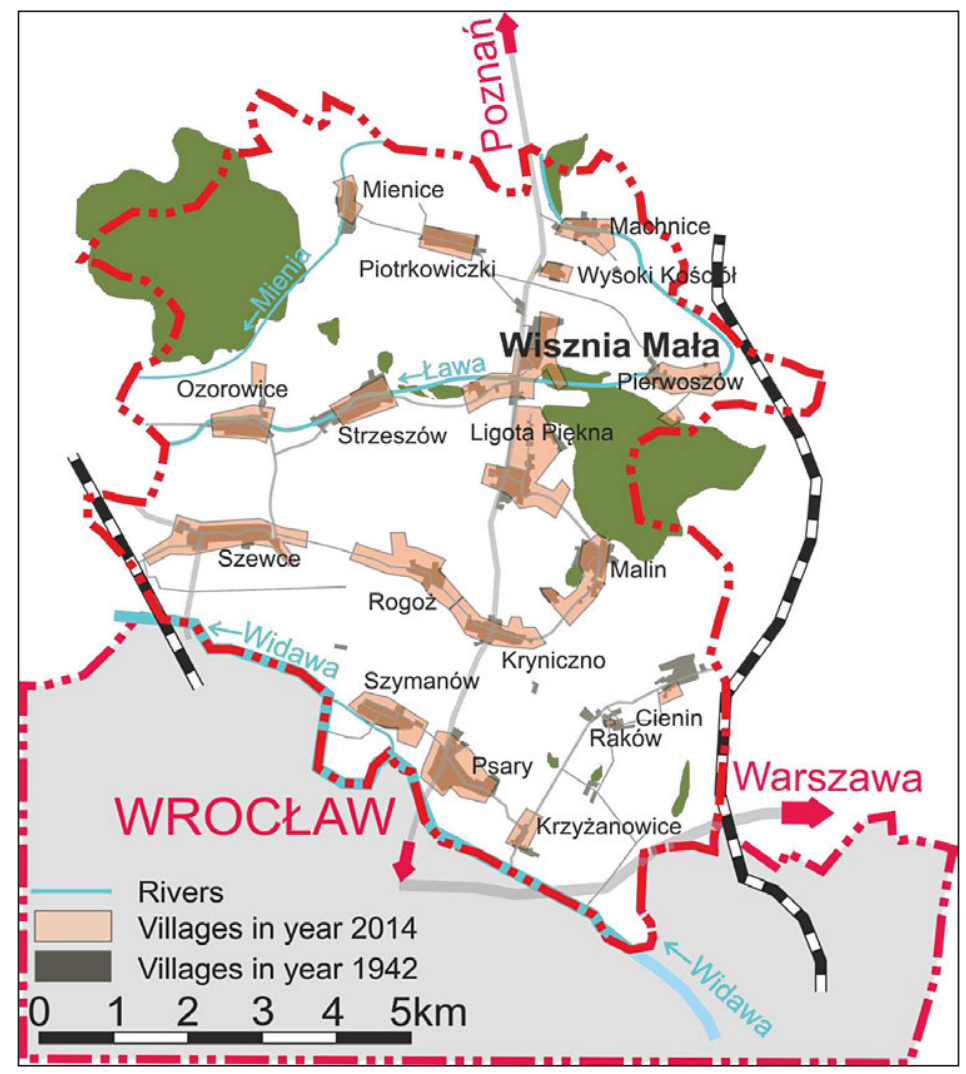

Figure 1. The development of the commune of Wisznia Mała between 1942 and 2014 year

Table 1. Summary of surface waters in the villages from the commune of Wisznia Mała

\begin{tabular}{|c|c|c|c|c|c|}
\hline \multirow[b]{2}{*}{ No. } & \multirow[b]{2}{*}{ Name of the village } & \multirow[b]{2}{*}{$\begin{array}{l}\text { Watercourses, } \\
\text { streams and rivers }\end{array}$} & \multicolumn{3}{|c|}{ Stagnant waters ponds (numer) } \\
\hline & & & \begin{tabular}{|c|} 
within residential areas at the \\
beginning of the twentieth \\
century $1 / 2002^{2} / 2014^{3}$
\end{tabular} & \begin{tabular}{|c|} 
in the immediate vicinity of the \\
built-up areas at beginning of the \\
twentieth century $2002 / 2014$
\end{tabular} & Total \\
\hline 1 & Kryniczno & 0 & $4 / 3 / 1$ & $4 / 0 / 1$ & $8 / 3 / 2$ \\
\hline 2 & Krzyżanowice & Widawa - nearby & $1 / 0 / 0$ & $0 / 0 / 0$ & $1 / 0 / 0$ \\
\hline 3 & Ligota Piękna & 0 & $1 / 1 / 1$ & $2 / 2 / 3$ & $3 / 3 / 4$ \\
\hline 4 & Machnice & Ława - nearby & $4 / 2 / 4$ & $0 / 0 / 0$ & $4 / 2 / 4$ \\
\hline 5 & Malin & 0 & $1 / 1 / 1$ & $2 / 2 / 2$ & $3 / 3 / 3$ \\
\hline 6 & Mienice & Mienia - along & $1 / 0 / 0$ & $0 / 0 / 0$ & $1 / 0 / 0$ \\
\hline 7 & Ozorowice & Ława - along & $1 / 1 / 1$ & $0 / 0 / 1$ & $1 / 1 / 2$ \\
\hline 8 & Pierwoszów & Ława - crosswise & $3 / 1 / 0$ & $0 / 0 / 1$ & $3 / 1 / 1$ \\
\hline 9 & Piotrkowiczki & 0 & $2 / 0 / 0$ & $0 / 0 / 0$ & $2 / 0 / 0$ \\
\hline 10 & Psary & Widawa - nearby & $2 / 2 / 2$ & $2 / 2 / 2$ & $4 / 4 / 3$ \\
\hline 11 & Rogoż & 0 & $4 / 3 / 3$ & 0/1/1 & $4 / 4 / 4$ \\
\hline 12 & Strzeszów & Ława - along & $4 / 2 / 2$ & $3 / 0 / 0$ & $7 / 2 / 2$ \\
\hline 13 & Szewce & 0 & $3 / 1 / 1$ & $0 / 0 / 0$ & $3 / 1 / 1$ \\
\hline 14 & Szymanów & Widawa - nearby & $1 / 0 / 0$ & $2 / 3 / 3$ & $3 / 3 / 3$ \\
\hline 15 & Wisznia Mała & 0 & $8 / 4 / 4$ & $1 / 1 / 1$ & $9 / 5 / 5$ \\
\hline 16 & Wysoki Kościół & 0 & $1 / 0 / 1$ & 0/1/1 & $1 / 1 / 2$ \\
\hline \multicolumn{3}{|c|}{ TOTAL } & $41 / 21 / 21$ & $16 / 12 / 16$ & $57 / 33 / 37$ \\
\hline
\end{tabular}

Comments: 1 - messtischblatt [amzp.pl]; 2 - [Niedźwiecka-Filipiak 2002]; 3 - based on field research. 
flowing along the built-up areas (Mienice, Ozorowice and Strzeszów), and in one example also flowing crosswise to the village (Pierwoszów). Krzyżanowice, Psary and Szymanów are located in the vicinity of the river Widawa that flows beside the built-up areas.

During the analysis of the amount of water reservoirs in the studied localities it was concluded that within approx. 100 years their number in urban areas have declined sharply, it is now a half smaller. Liquidated water reservoirs inside the old manor complexes (eg. Mienice), in the center of the village (eg. Ozorowice), the mill ponds (eg. Strzeszów) and other, particularly the small ones. Over the last 10 years the total number of all ponds inside the village has not changed, but the differences are in the various localities. Unfortunately, water reservoirs, especially those small are still being backfilled. Such examples are villages Kryniczno and Pierwoszów. In Kryniczno, following the map from year 1942, there were four water reservoirs inside the village (Figure 3). One of them was located inside the manor farm buildings, another was situated nearby and the other two had probably economic and retention functions. Even in 2002, in the village three water reservoirs were located there. The one situated near the mansion have been backfilled, but the another one located nearby was still preserved. However, it was overgrown by vegetation and neglected. The third pond, which was situated near the church, in the meantime was turned into a concrete fire protection reservoir, fenced with a mesh and became inaccessible due to the dangerous steep banks. The last pond was located within the private property, during this time its size had been reduced but the pond is now well-maintained with the addition of the bridge, however, not very visible from the road. Over the last 10 years, another two ponds were filled. The only one which remained was the one located within the private area. The new reservoir located in the vicinity of built-up areas of the village is overgrown and neglected (Figure 4).

In terms of water reservoirs situated in the immediate vicinity of the built-up areas the quantitative changes are much smaller. Their number decreased till 2002, but in the last 10 years has risen to the status of the early twentieth century (Figure 2). The biggest changes concern the development of the two recreational areas, in which new water reservoirs were created. The first is the restaurant Miłocin with water reservoir in Pier- woszów. The other is a golf course, in which there are currently six major water reservoirs and a few smaller ones, along with the Toya Golf housing estate. These sites are an example of good use of water reservoirs and creating them attractive not only for the residents of the commune, but also for Wroclaw's inhabitants and in the case of golf courses also the region.

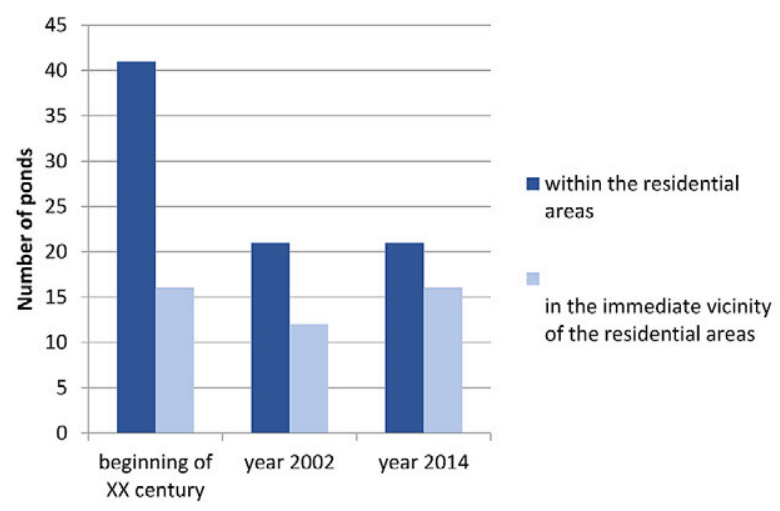

Figure 2. Number of ponds with division on ponds within the residential areas and ponds which are in the immediate vicinity of the residential areas

However, it should be noted that in any villages from the studied area the potential of watercourses flowing through the villages was not used to improve the quality of space around. In the village of Mienice a small part of the river surroundings within the private property have been developed in a model way (Figure 5), while within the area around the common building located by the river, the values of water haven't been taken into account. The building is fenced, cut off from the watercourse, both functionally and visually (Fig.6). Although the public space could be enlarged by designing a descent to the water and including the river into the project, as was it done in the private property. It should be added that this is not a bad will of the inhabitants, more the lack of awareness, because the village is well cared for, and its inhabitants are active.

\section{RESULTS}

\section{Contemporary functions of water reservoirs. Good practices from Poland and from abroad}

The example of the right approach to the potential of existing resources and the use of surface waters in shaping the rural landscape is the village Rumbau located in Rhineland-Palatinate in Germany. The village currently has 480 residents, the 


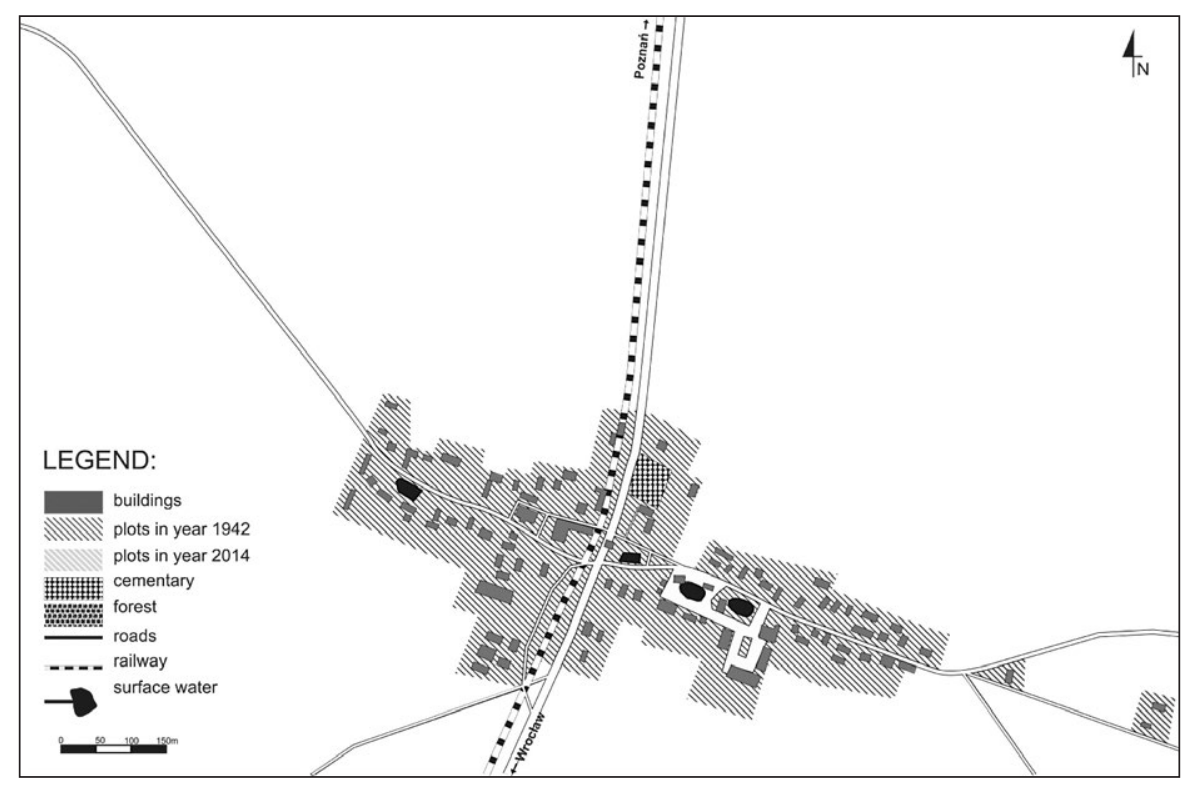

Figure 3. Kryniczno in the year 1942, there are 4 ponds visible

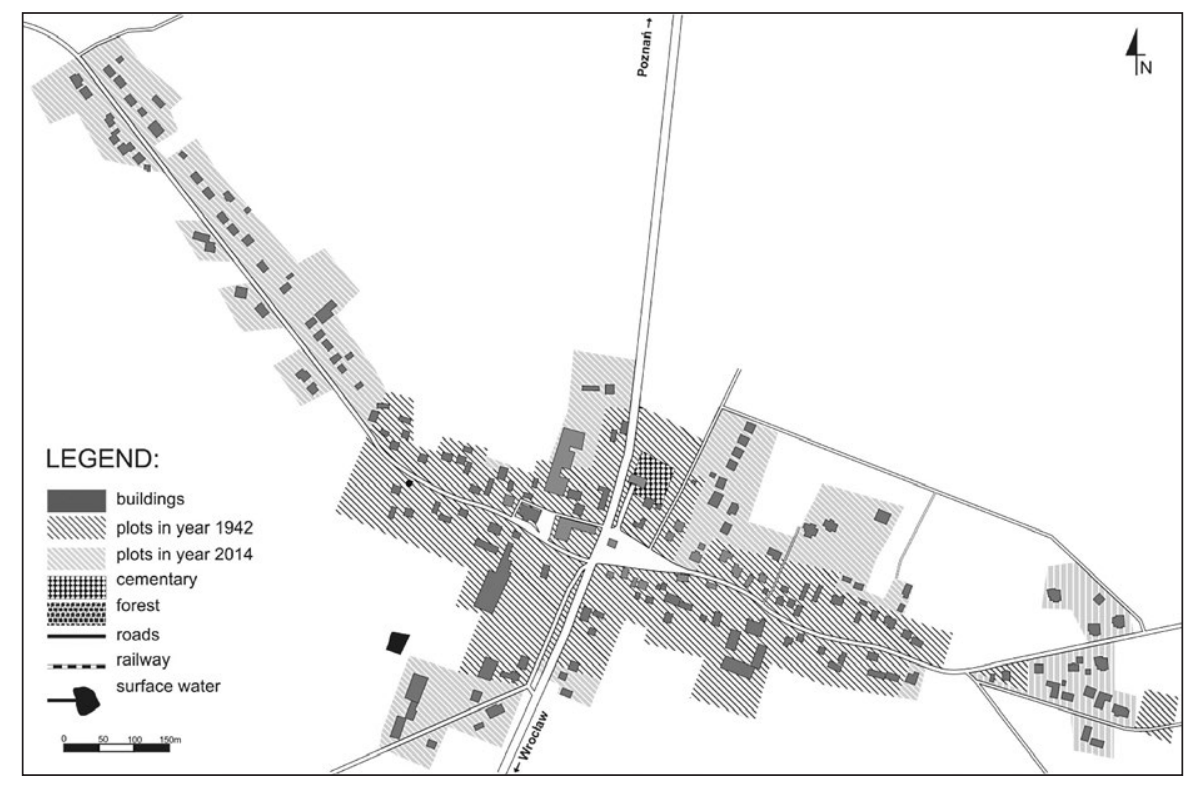

Figure 4. Kryniczno in the present time, with one small pond

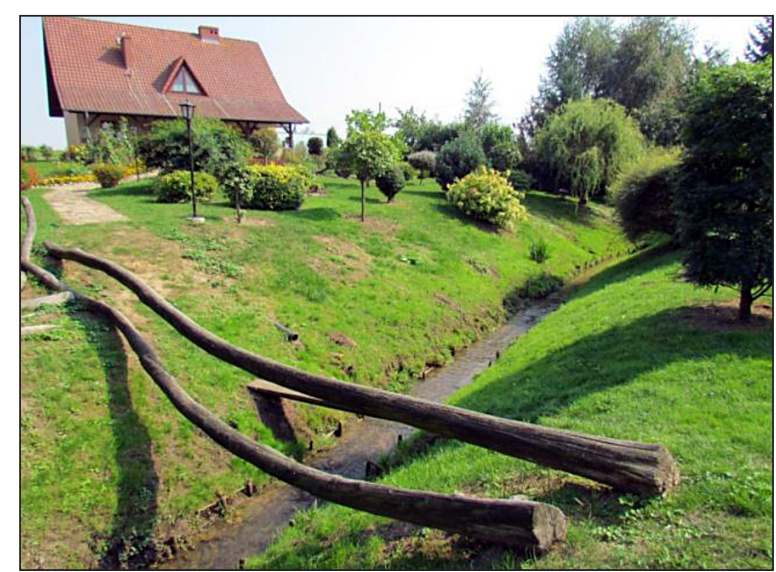

Figure 5. Mienice. The development of the neighbourhood of the river on a private property

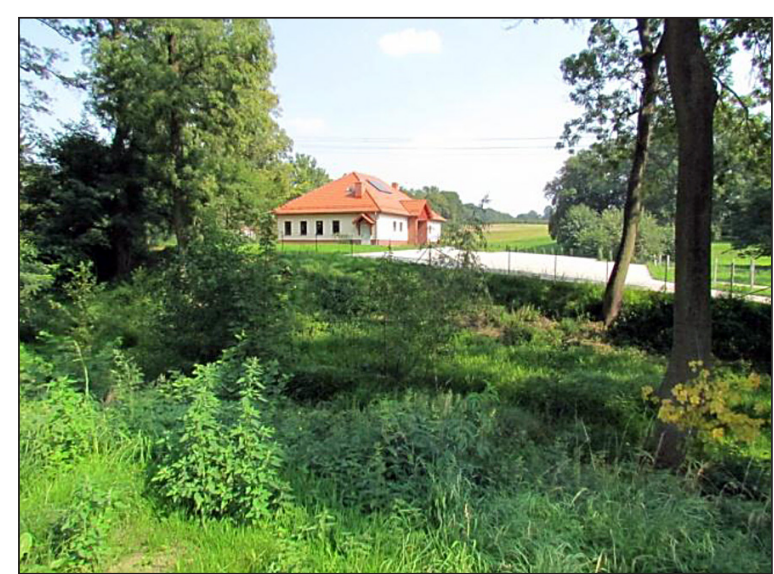

Figure 6. Mienice. On the first plan the undeveloped surroundings of the river, which is isolated from the common building by a fence 
area of the village covers about 1,500 hectares, of which 1,000 hectares are forests. The village has a pond and touristic trail called "Rumbach and its springs". Each of the seven springs and wells is properly exposed and beard with the information board. Examples are shown on Figure 7 and 8. Inside the village there is also a small water reservoir. The project of this reservoir and its surroundings takes into account children's playing area, recreation for the elderly, as well as places where all residents can make barbecue or play active sports. It is now under construction. The idea of Sebastian Kneipp, which involves treat-

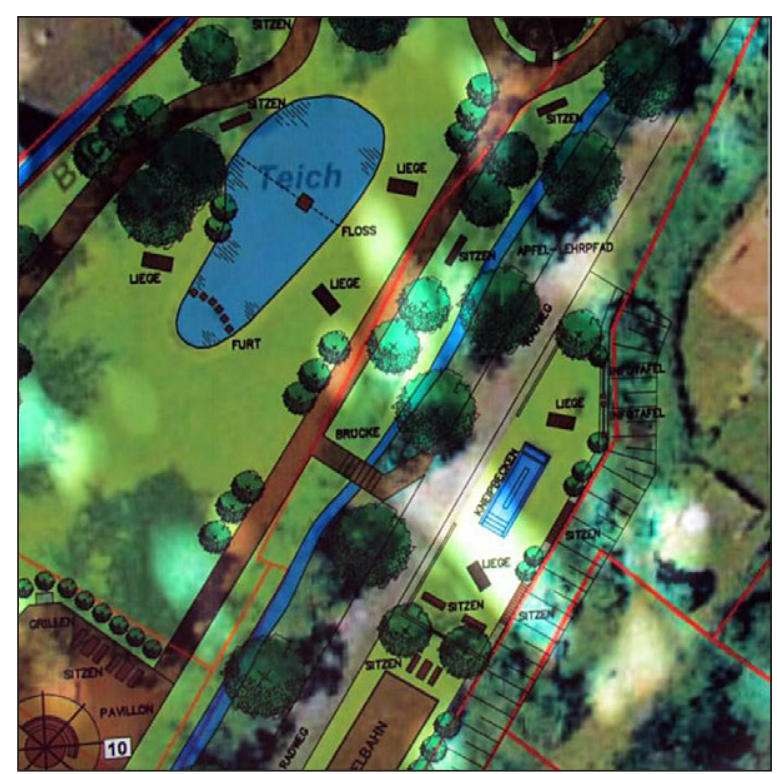

Figure 7. Fragment of the plan of development of the interior of the village with use of the pond, below Kneipp therapy pool

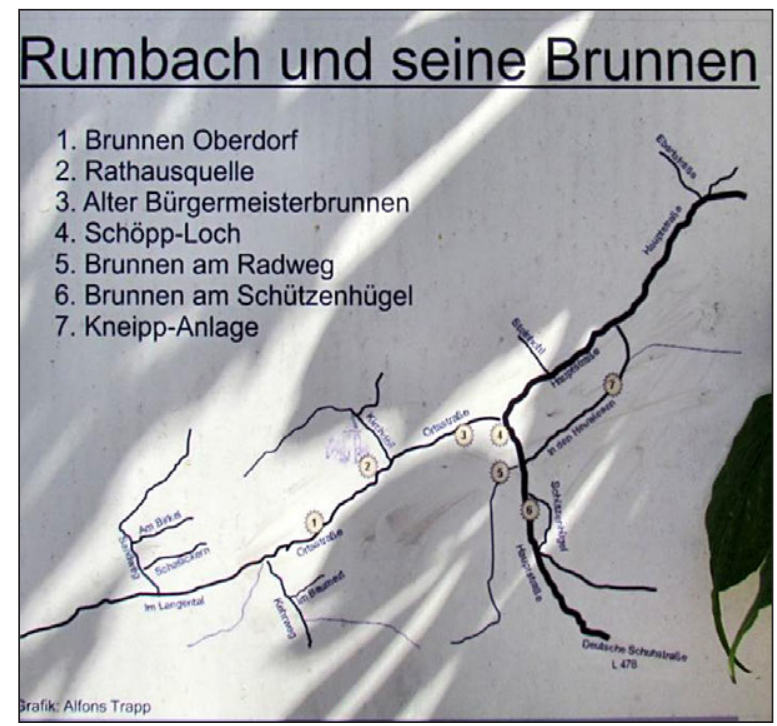

Figure 8. Sketch of the stream flowing through the village along with showing the location of seven springs ment by immersion in cold water was used also in the project. Most treatment is based on walking in water or putting hands into it. The idea is being used in Germany for example in nurseries for hardening the health of children. In the end of the nineteenth century Kneip developed the comprehensive system including regenerative-healing program based on the beneficial effect of water. Inspired by this idea in Rumbau, next to the pond the engineers planned small oblong pool with comfortable handrails enabling easy entrance to it for all interested persons, including the elderly.

Another example of good practice is an ongoing project of land development of area by a small river in the village of Ottersheim in Germany, Rhineland-Palatinate (Figure 11). This project is worth showing because without the residents of the village the realization of it would not be possible. Earlier the area adjoining the river was consisted of the private plots. Because this was the area of floodplains, there were gardens and or-

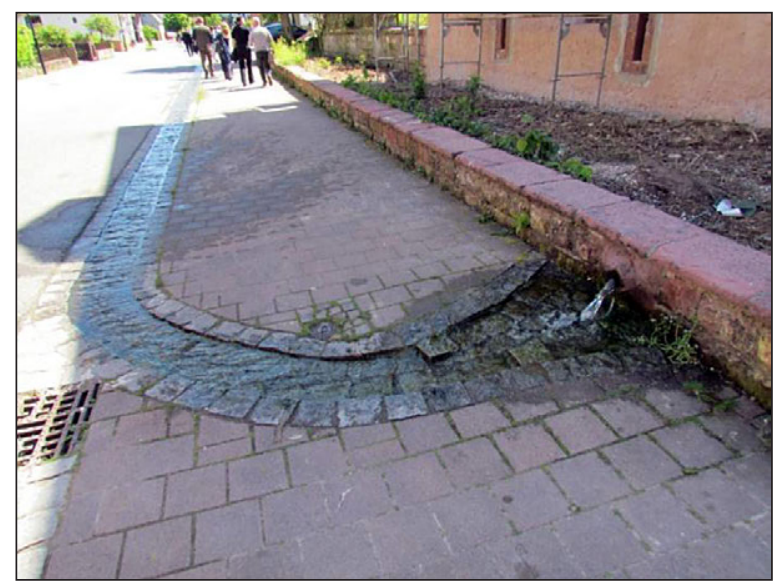

Figure 9. Spring number 3. The water flows freely in the gutter along the street

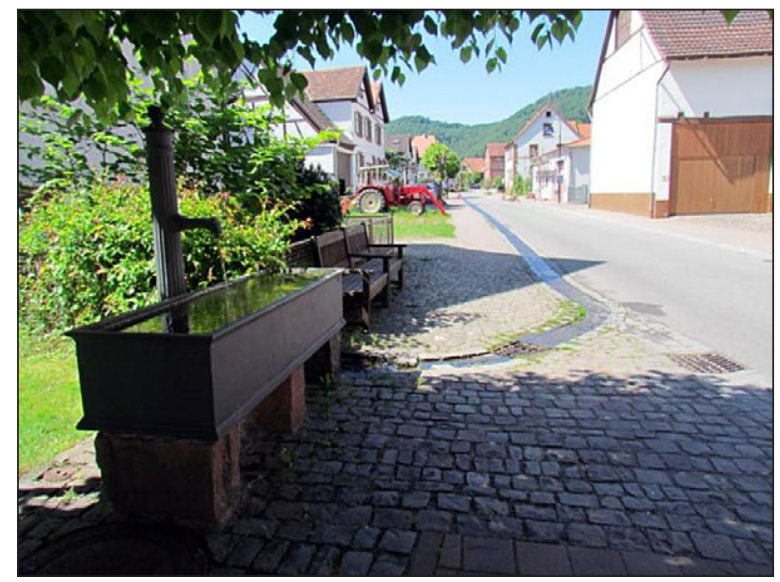

Figure 10. The so-called Mayor Spring 


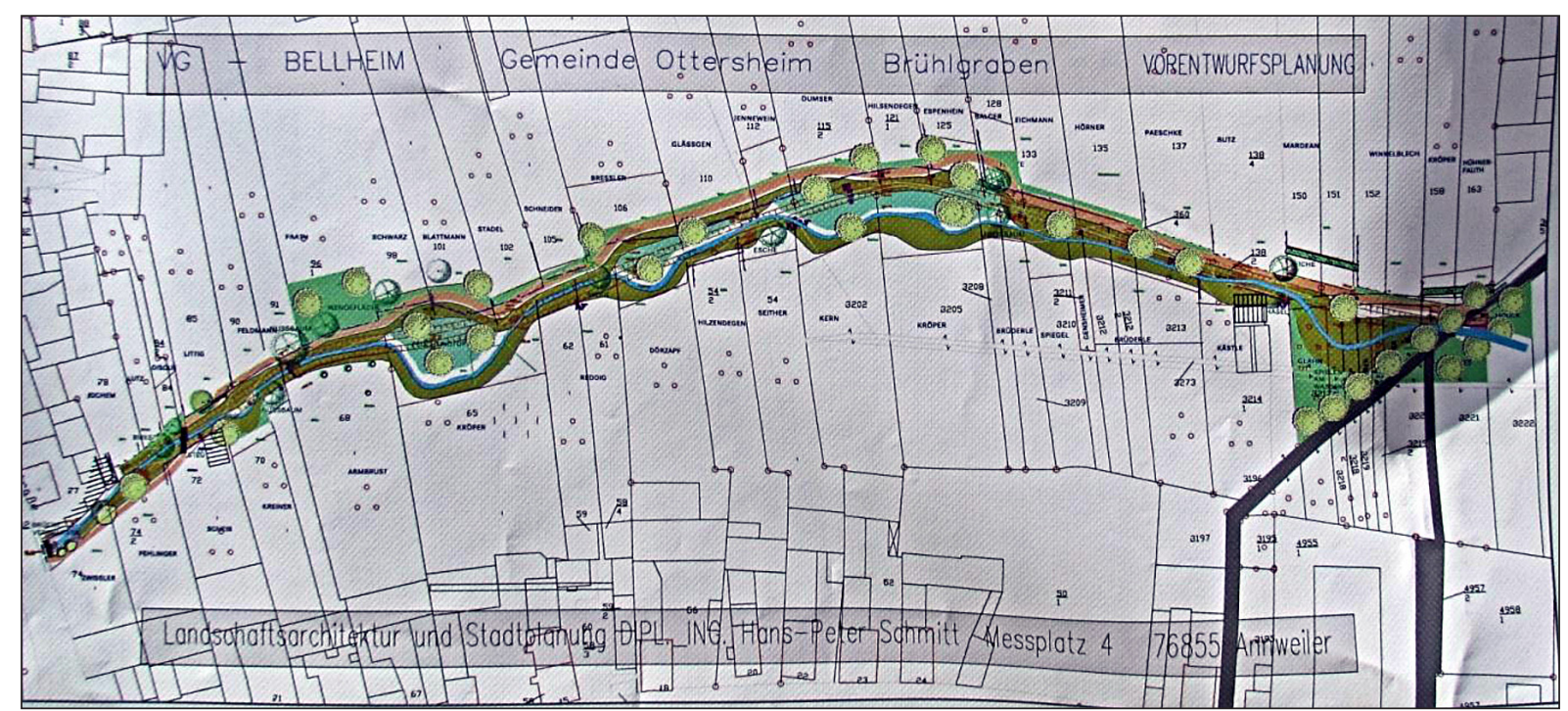

Figure 11. Ottersheim, the development plan of the area by the river-realization is planned till year 2018

chards. In the village there was little public space being favorable for integration of the inhabitants. It was therefore decided by the commune to buy the fragments of private plots adjoining the river at a symbolic price (with the consent of the inhabitants). That enabled the creation of the promenade with scenic places to rest and new public space favorable for the integration of the inhabitants.

Different example of the village, where the surface waters are partially used, is the village of Bagieniec located in the commune of Świdnica. The surface waters in the village were used as early as at the beginning of the twentieth century (Figure 12). Then the inhabitants of the nearby town of Świdnica were comming to Bagieniec, searching for the ability of resting in peace among the ponds and green areas. Today, the complex of preserved ponds is used again for fishing and as a recreational area (Figure 13).

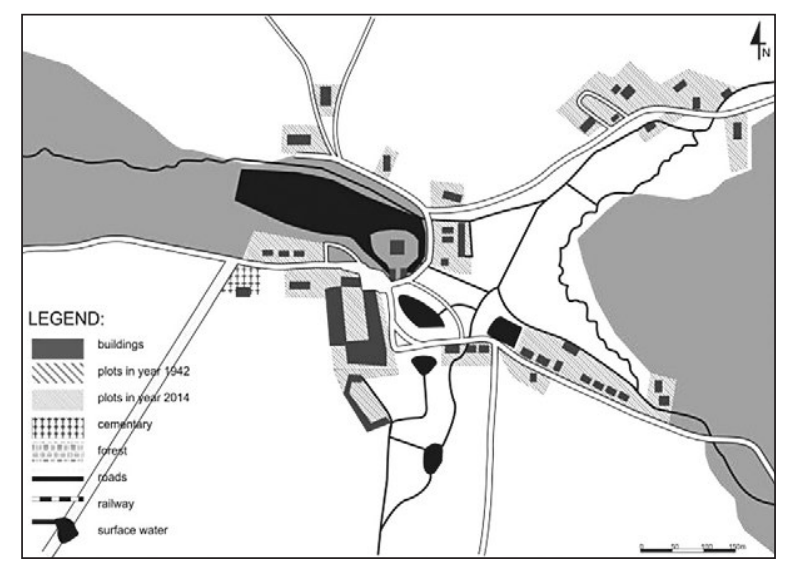

Figurte 12. The village Bagieniec in 1942

\section{CONCLUSION}

Former economic function of surface waters in the villages has changed and now they have lost their former rank. As shown on the example of the analyzed commune, the biggest changes concern small water reservoirs within residential areas, from which many were liquidated during the last 100 years. Although having the potential of performing the representative functions, being a place for recreation and the decoration of the village, only a small proportion of the small water reservoirs, which remained, is properly managed. Residents do not see their potential, rather only trouble and breeding area for onerous mosquitoes. Similarly, the potential of rivers, streams and watercourses flowing through the villages is not used. With appropriate land development they could also conduct representative and recre-

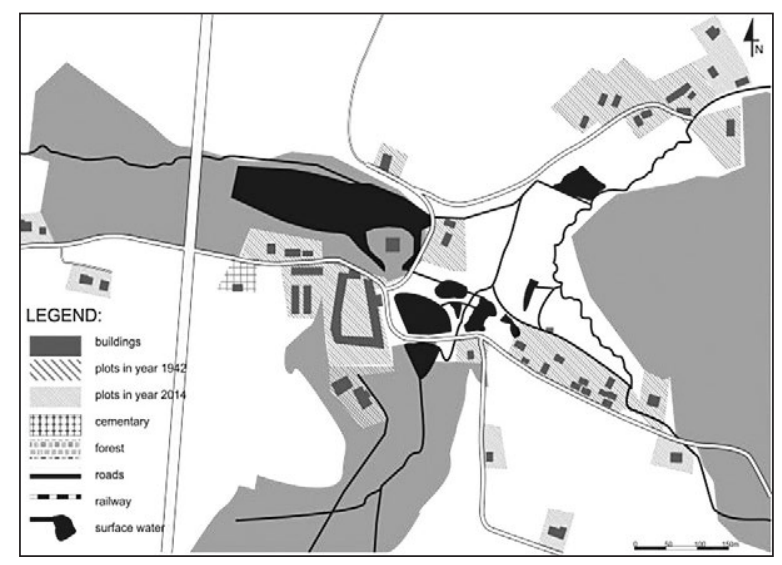

Figure 13. The village Bagieniec now 
ational function. The best used examples of water reservoirs are larger ponds located outside the villages. They are used as for fishing and swimming purposes. These water reservoirs are the base around which the areas with recreational and touristic function are built.

\section{REFERENCES}

1. Bernat S. 2003. Woda w Krajobrazie parków wiejskich doliny Bugu. Woda w przestrzeni przyrodniczej i kulturowej. Prace komisji krajobrazu kulturowego t II. Wydawnictwo Komisja Krajobrazu Kulturowego PTG, Sosnowiec, p. 38.

2. Borcz Z., Pogodziński Z. 1994. Woda w krajobrazie wiejskim - zagrożenia i ochrona. Zeszyty Naukowe AR we Wrocławiu, Monografie, p. 236.

3. Borcz Z., Potyrała J. 1993. Egzystencja i przyszłość wiejskich stawów. Zeszyty Naukowe AR we Wrocławiu, 231, 335-343.

4. De Groot R. 2006. Function-analysis and valuation as a tool to assess land use conflicts in planning for sustainable, multi-functional landscapes. Landscape and Urban Planning 75, 175-186.

5. Iwicki S. 1997. Znaczenie zasobów wodnych w rozwoju turystyki na obszarach wiejskich. Woda jako czynnik warunkujący wielofunkcyjny i zrównoważony rozwój wsi i rolnictwa. Wydawnictwo IMUZ, Falenty, p. 209.

6. Kaca E. 2009. Gospodarka wodna wsi i rolnictwa. I Kongres Nauk Rolniczych, Nauka w Praktyce: przyszłość sektora rolno-spożywczego i obszarów wiejskich, Puławy, 93-104.

7. Marcucci D.J. 2000. Landscape history as a planning tool. Landscape and Urban Planning 49, 67-81.

8. Niedźwiecka-Filipiak I. 2002. Wpływ wód powierzchniowych na układ przestrzenny wsi. Inżynieria Rolnicza 3 (36), 383-392.

9. Niedźwiecka-Filipiak I., Zielińska L. 2013. Zieleń w krajobrazie wsi podmiejskich Wrocławia. Planowanie krajobrazu - wybrane zagadnienia, Wydawnictwo PAN, Uniwersytet Przyrodniczy w Lublinie.

10. Przyjazne naturze kształtowanie rzek i potoków. 2006, thumaczenie z Manual of River Restoration Techniques, Wydawnictwo Polska Zielona Sieć, Kraków.

11. Wagner A. 2005. Znaczenie zbiorników wodnych w rozwoju ekoturystyki i agroturystyki w wybranych rejonach wiejskich w okolicach Krakowa. Przegląd Naukowy: Inżynieria i Kształtowanie Środowiska 2(32), 140-146. 